\title{
ECOTOURISM: TOWARDS SUSTAINABILITY OF EGYPTIAN LAKES
}

\author{
Dr. Zeinab Faisal \\ MTI University
}

\begin{abstract}
"Both human civilizations and the natural ecosystems represent integral parts of our environment ${ }^{\prime \prime 1}$. With the new century planners and governments face big challenge which is population has been increasing and resources decreased. That's why it is vital to create new methods to get new opportunities for upgrading the quality of life and to get new economic resources towards filling the gap between population increase and limited resources. Development of lakes with their distinguished nature can be a part of this challenge. Lakes are extremely sensitive environments, whose status represents the equilibrium among climatic conditions, hydrological setting and human pressure. This equilibrium is particularly fragile in arid environments. ${ }^{2}$
\end{abstract}

Lakes in Egypt are very special case because they enclose many kinds of environments: desert, water and green areas in addition to the natural protectorates with in. These protectorates saved from ancient ages and protected by law and international agreements.

So upgrading waterfront of lakes is one of the important targets for researchers, scientist, architects, planners and the government. The study highlights the ability of waterfront development in Egyptian lakes to achieve sustainability. The research problem focuses on how to use ecotourism projects in upgrading waterfront areas in Egyptian lakes with caring of natural life, social life and economic needs to achieve sustainable development goals. Research methods include the analysis of the current situation of lake area in Egypt and define the problems, the comparison between international projects, and determining the steps used in planning and design upgrading lakes waterfront in Egypt.

Keywords: Ecotourism, Sustainable development, lakes, quality of life.

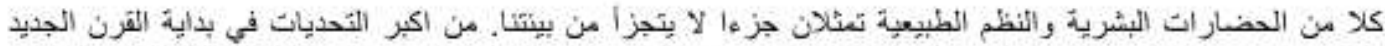

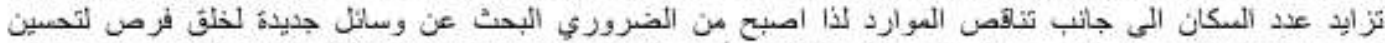

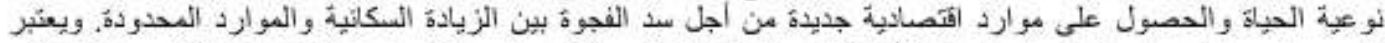

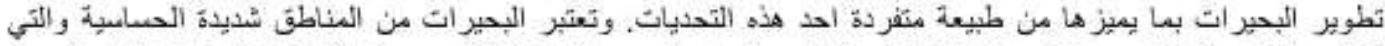

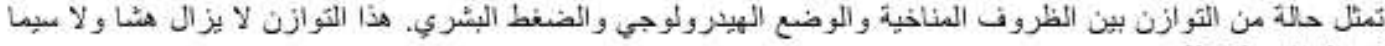
في الليئات القاحلة.

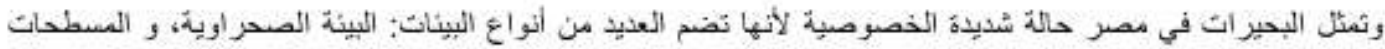

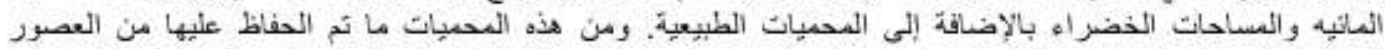

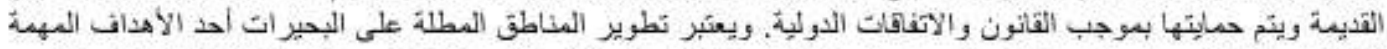

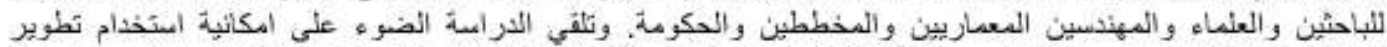

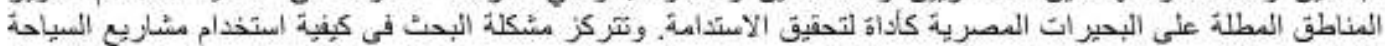

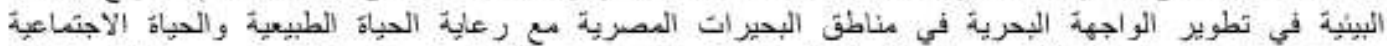

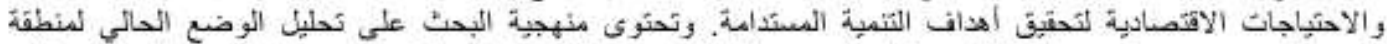

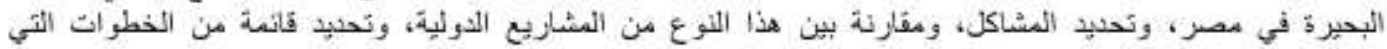

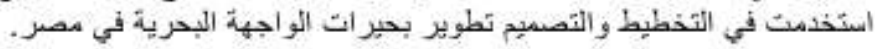
الكلمات الزينيسية : المباحة البينية والتنمبة المستداهة، والبحير اث، وثو عبة الحياة. 


\section{INTRODUCTION}

Egypt possesses one of the most developed and diversified economies in the Middle East, with sectors such as tourism, agriculture, industry and service at almost equal production levels. The Egyptian economy is rapidly developing, due in part to legislation aimed at luring investments, coupled with both internal and political stability, along with recent trade and market liberalization.

Water area is $6 \%$ of Egypt's area, divided into three kinds: seas (Mediterranean and Red Sea), lakes and the River Nile. Water front projects play very important role in touristic field, fishing, agriculture and urban life .the population in Coastal cities is $\mathbf{5 0}$ $\%$ of Egypt .water front projects in Egypt normally are used in touristic field, for example al Gouna resort at the Red Sea marina and Marasy at the Mediterranean Sea, river Nile beach is used in touristic cities like Cairo, Aswan and Luxor.

Egypt has a large number of inland lakes, the largest of which are the freshwater Lake Nasser and the saline Lake Qarun in Fayyoum. The coastal zone is home to numerous highly populated economic centers, such as the cities of Alexandria, Damietta, Hurghada, Port Said, Suez, and Sharm El Sheikh.

\section{CONCEPT OF SUSTAINABLE DEVELOPMENT}

According to the World Commission on Environment and Development "sustainable development is development that meets the needs of the present without compromising the ability of future generations to meet their own needs. It contains within two key concepts: the concept of 'needs' in particular the essential needs of the world's poor, to which overriding priority should be given; and the idea of limitations imposed by the state of technology and social organization on the environment's ability to meet present and future needs. ${ }^{33}$ Environment issues are getting attention worldwide. These issues include not only updating the guidelines and regulations that enforce sustainable development, but also the economic incentives to incorporate sustainable development designs. The news media began to publicize environmental concerns nationally, and the resulting public awareness spurred major legislation, which enabled planners to incorporate ecological values. ${ }^{4}$

\section{ECOTOURISM AND SUSTAINABLE DEVELOPMENT}

The challenges confronted by coastal protected areas in both promoting highly attractive sites and preserving the natural qualities of these sites have been given a new aspect with the opportunities presented by ecotourism. Ecotourism has a great power on the environment, and it does not need widespread infrastructure in comparison to other types of tourism. Ecotourism as a concept includes a wide range of activities, from field research of flora and wildlife to weekend nature outings that combine leisure and education (Nikitinskiy, 2001).

The International Ecotourism Society in 1991 produced one of the earliest definitions: "Ecotourism is responsible travel to natural areas that conserves the 
environment and sustains the well-being of local people." It refers to low-impact, nature-based tourism that causes less negative effects on a destination's environmental, social, and economic resources than conventional mass tourism, and it can be used as an effective sustainable development tool (Horochowski \& Moisey, 2001). The World Conservation Union (1996) explains that ecotourism "is environmentally responsible travel and visitation to relatively undisturbed natural areas, in order to enjoy and appreciate nature (and any accompanying cultural features-both past and present) that promotes conservation, has low negative visitor impact, and provides for beneficially active socioeconomic participation of local populations."

This could be called, as a concept, ecotourism resources management. Ecotourism resources management is a component of the field of sustainable tourism development (Buckley, 2001, Pigram, 1997; Wight, 2001; Wood \& Halpenny, 2001).

\section{ECOTOURISM: FIELDS OF ATTRACTIONS}

There are three groups of attraction: built, natural and social/cultural attractions.

Built refers to an enormous range of structures that includes heritage, accommodation, places for entertainment, transport infrastructure, worship, commerce, learning and government as well as zones where people gather.

Natural include areas where nature dominates or is predominate and includes shorelines, river banks, undisturbed land where natural ecosystems continue to function and parks.

Social/cultural experiences refer to those activities that focus on the human experience and while taking place within a built structure or in nature are centered on interaction between people. These forms of experiences are diverse and may include concerts, shopping, entertainment, sport, recreational activities, theatre and etc.

Visitors usually have been offered a range of built attractions and social/cultural experiences. On the other side they don't have a great diversity of natural experiences and to meet this area of tourism natural attractions may need to be developed.

\section{LAKES AND ECOTOURISM}

Water is an attractive element and plays an important role in recreation. Besides coastal tourism, a large number of lake and wetland destinations can be found worldwide. Lakes are extremely sensitive environments, whose status represents the equilibrium among climatic conditions, hydrological setting and human pressure. This equilibrium is particularly fragile in arid environments. Most of those lake and wetland destinations are very different in terms of morphology, climate, culture, traditions, and so on. Nonetheless, they show also several similarities concerning 
their features, development potentials and the threats they are exposed to, including those caused by tourism. During the last two decades the environmental awareness of both, tourists as well as tourism entrepreneurs, has improved and due to that, concepts of sustainable ecotourism and other forms of "new tourism" have emerged.

\section{INTERNATIONAL EXAMPLES OF SUSTAINABLE LAKES ECOTOURISM}

Successful tourism development depends on a proper balance of the use of environmental resources - as a basic ingredient of tourist products - and the negative environmental effects tourism might cause to the environment and nature. There is quite a consensus that finite resources (i.e., beaches etc.) and their quality are limiting factors for tourism development.

A survey of the BAT-Institute published in August 2006 states, that tourism and recreation will be the motor for economic development in the 21th century. In Germany, like many other countries, the leisure, tourism and recreation business is today the largest employer by far, with over 6 Million employees. And ecotourism is the fastest growing segment of the travel industry. As a result, community groups as well as NGOs increasingly see ecotourism as an opportunity to generate income and improve livelihoods and employment, particularly in rural areas.

\subsection{Example from China: \\ Crosswaters Ecolodge, Nankun Mountain Reserve, Guangdong Province}

Throughout China, rapid industrialization is causing millions of people to migrate from the countryside to cities like Guangzhou. As urban areas sprawl outward, new development consumes open land and critical natural resources. This pattern of development is causing widespread environmental devastation and social disruption that is risking China's long term future.

Crosswaters Ecolodge is placed within a 260-square kilometer protected forest called Nankun Mountain Reserve, 80 miles from the city of Guangzhou in southeast China. The resort has 53 suites and villas built with locally sourced materials like bamboo. A community of more than 5,000 native Keija people live within the reserve. They helped to plan, build, and operate the sustainability-minded resort. There are over 1,300 types of plants in the park with over 30 square kilometers of native bamboo. Over 74 bird species and more than 176 species of butterflies exist in the reserve. All new plantings are native species.

The resort, which is the first ecotourism destination in China, respectfully leverages the natural splendor of the land to provide guests with engaging outdoor activities, delicious local food, and breathtaking scenery. Income from the resort helps fund forest conservation. The Nankun Mountain Reserve was created in 1984 in an effort to preserve 260-square kilometers of native evergreen forest. Located within the reserve on a mountain above the Ganken River, Crosswaters Ecolodge was created as a sustainably-minded hotel and resort featuring 53 villas and suites. 
Figure (1) Crosswaters Eco-lodge site plan

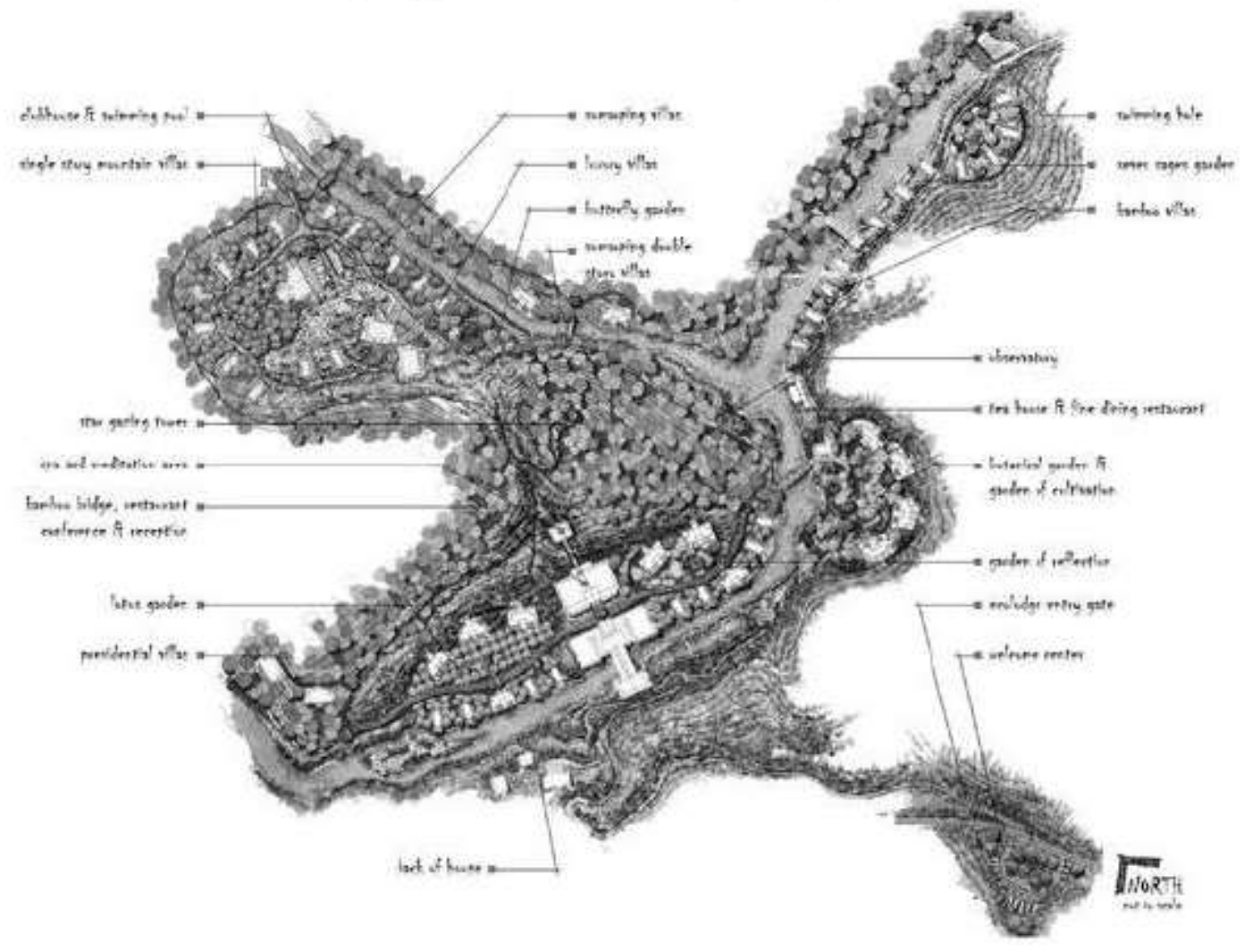

More than 5,000 native Keija people live within the reserve. During the planning process, landscape architects consulted the community to learn the history of the land and native culture. Local residents offered insight into the project proposal, shown above. The community planning process helped increase the community's sense of ownership and appreciation for the new development.

Figure (2) Crosswaters Eco-lodge

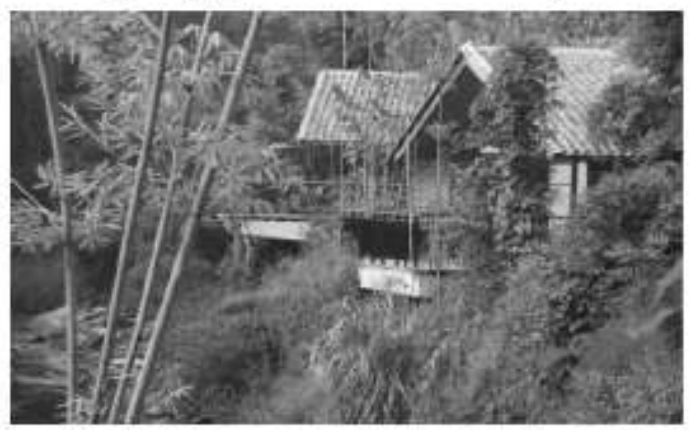

Figure (3) Bamboo bridge

Local Keija craftsman and artisans were employed in constructing nearly all aspects of the lodge, even complex structures like this bamboo bridge, which spans the Ganken River. Here, local workers were mentored by expert craftsman to learn new construction techniques. The community benefits as local craftsman gain new skills that can be applied on future projects.

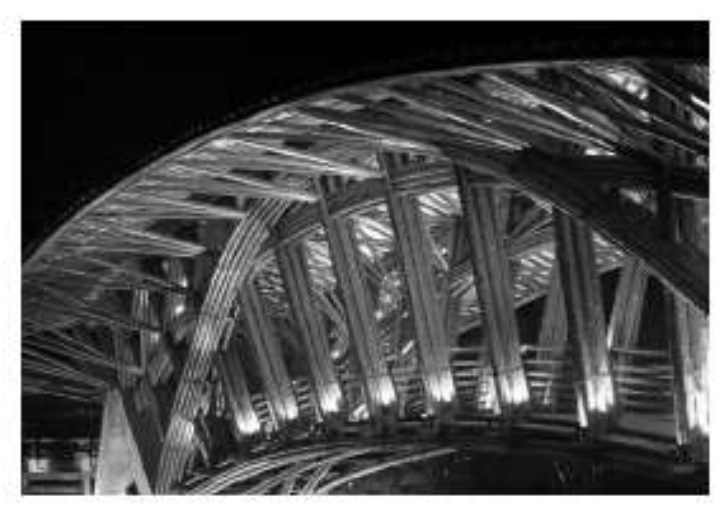


Buildings, structures, and paving

Figure (4) Using local materials in buildings around the resort all incorporate local materials such as bamboo, clay tiles, marble, and river stones. The restaurant and lounge, shown here, feature bamboo flying buttresses that honor the traditional architecture of southeast China. Guests enjoy views from the open-sided restaurant while enjoying hearty local dishes, prepared with organic vegetables grown on site.

The local community engages with the resort on many levels, providing guests with insight into the sustainable lifestyles of rural China. Here, in the "Garden of Cultivation," Keija farmers cultivate and harvest native fruits and vegetables that supply the kitchen. Guests of the resort see and taste the advantages of local food production

Guests can interact with the landscape throughout their visit, choosing among a multitude of outdoor activities including mountain climbing, boating, birding, farming, or fishing.

At night, guests can star gaze from the outlook tower shown in Figure 6.

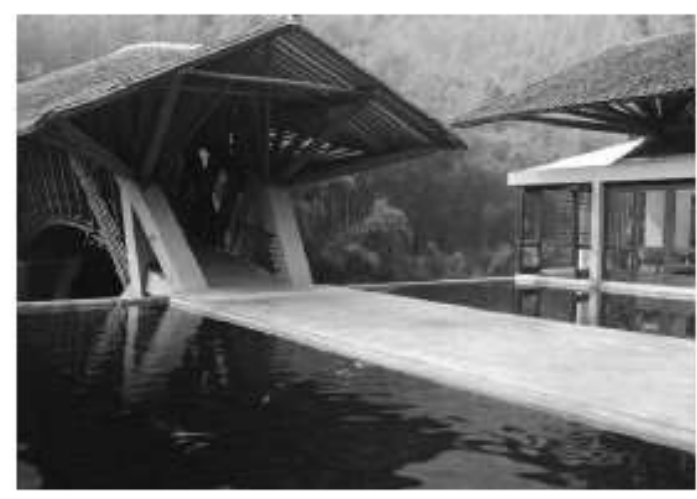

Figure (5) Farmers cultivate native fruits

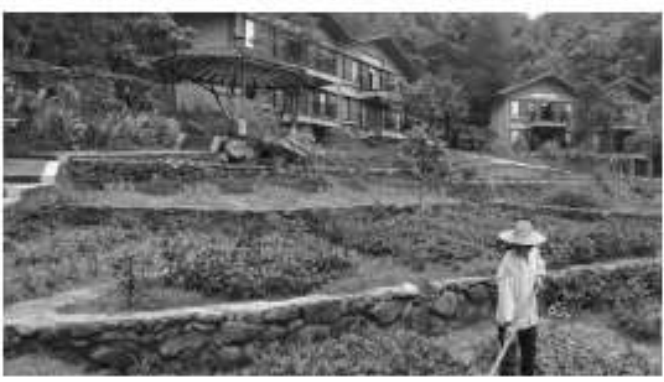

Figure (6) The wooden tower

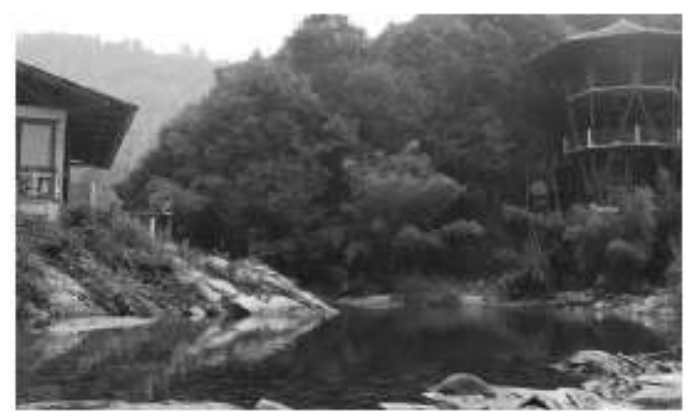

\subsection{Example from Panama: Isla Palenque}

Isla Palenque, a 434-acre Panamanian island, serves as a model for geo-responsible design practices throughout Central America, drawing upon natural, human-made and cultural patterns. The project preserves 85 percent of the island into a nature sanctuary, examines bioclimatic strategies for site-planning decisions, explores methods of ecotourism to decrease imports, and develops water and energy management plans that reduce dependency on nonrenewable resources. The project challenges existing governmental regulations, redefining regional development and conservation standards .

Preserving the island's environmental integrity took on the highest priority, limiting developing to only 15 percent of the island's coverage. The vision was to develop a model for sustainable island planning that expressed the place's true spirit. With loose development regulations throughout Central America, the vulnerability of 
many pristine sites has fallen to deforestation, out-of-scale development and traditional man-made recreational activities, all causing environmental repercussions. The landscape architect was instrumental in helping the client achieve his vision by synthesizing aspects of sustainability, ecotourism, conservation and education.

Figure (7) Isla Palenque project site plan

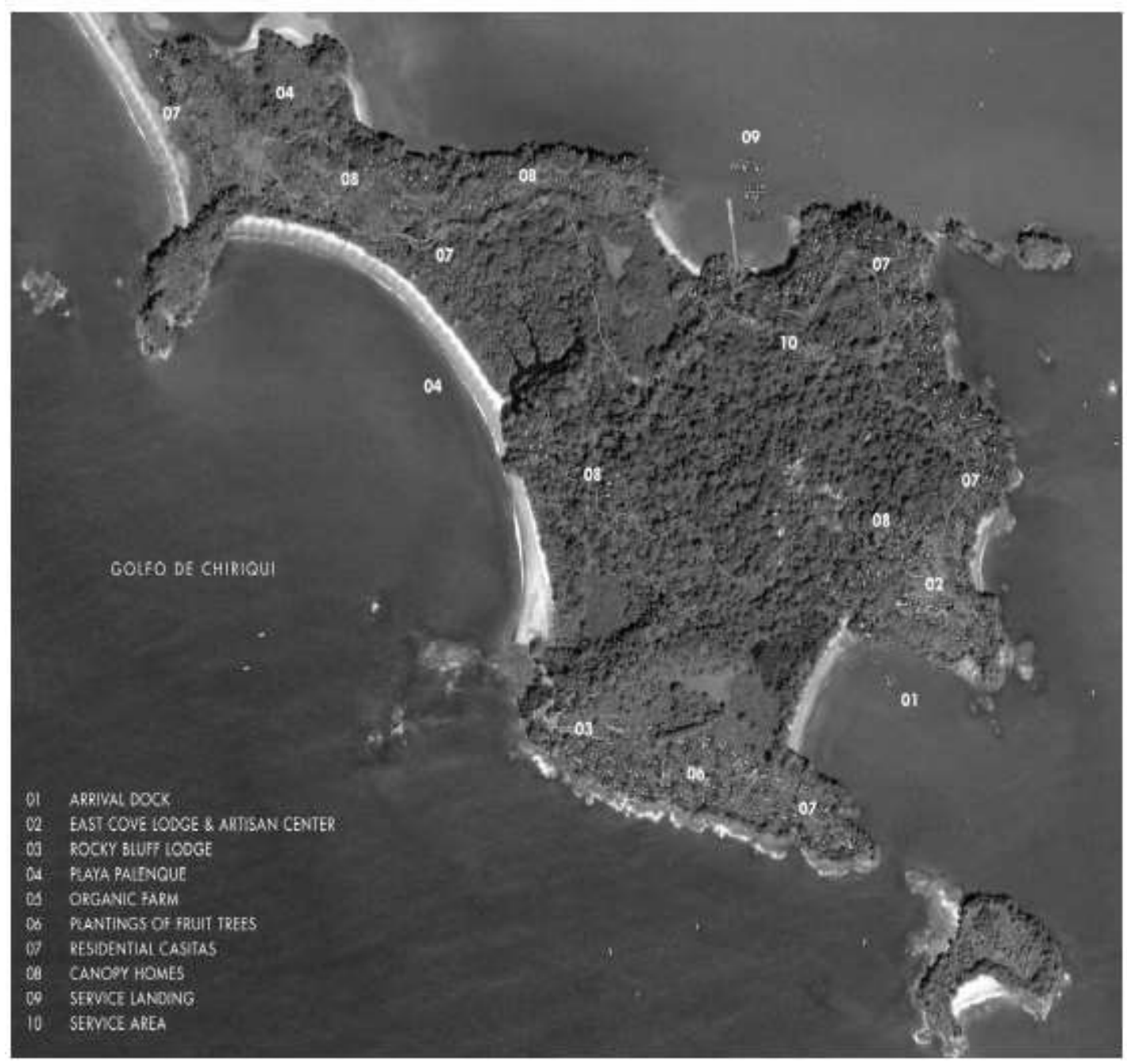

The project tries to achieve the aspects of ecotourism, "tourism that sustains, or enhances, the character of a place-its environment, culture, aesthetics, heritage, and the well-being of its residents." Ecotourism promotes a virtuous circle whereby tourism revenues provide a local incentive to protect what tourists are coming to see, but extends the principle beyond nature and ecology to incorporate all characteristics that contribute to sense of place, such as historic structures, living and traditional culture, landscapes, cuisine, arts and artisans, as well as local flora and fauna. 
The concept is effective and comprehensive. It combines the sustainable resort and eco-tourism. As part of the ecotourism concept, it seems that they spoke to the people who live there and the solutions were developed from their culture, which is very important. A comprehensive water and energy budget was developed for each project phase, comparing typical versus efficient demand to reduce dependency on utility services. 95 percent of projected energy needs will be generated by on-site solar and wind power.

Nestled into the jungle landscape, canopy homes were envisioned as light and airy structures elevated above the ground, responding to the given landform.

From their lifted position, structures capture trade winds and ocean views without compromising the integrity of the natural landscape.

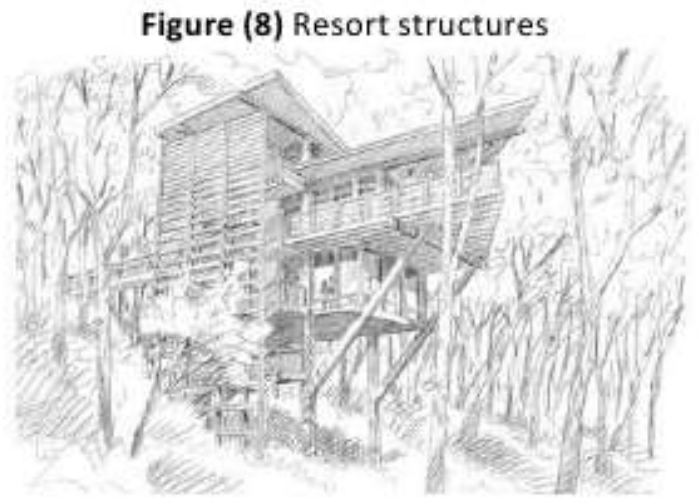

\subsection{Results and conclusions from international experiences}

- Ecotourism, "tourism that sustains, or enhances, the character of a place-its environment, culture, aesthetics, heritage, and the well-being of its residents.

- Buildings, structures, and paving are all incorporate local materials such as bamboo, clay tiles, marble, and river stones. Reduce dependency on nonrenewable resources.

- Successful tourism development depends on a proper balance of the use of environmental resources.

- Ecotourism as an opportunity to generate income and improve livelihoods and employment, particularly in rural areas. Income from the ecotourism could help fund natural conservation.

- Eco-tourism is usually a chance to employ local people.

- The community planning process helped increase the community's sense of ownership and appreciation for the new development.

- Using materials from surrounding environment more effective and getting harmony between project and site in addition to realizing sustainability.

- Using technology and communications with green materials to get an attractive landscape.

\section{TOWARDS SUSTAINABILITY OF EGYPTIAN LAKES:}

\subsection{Egyptian lakes}

"A lake is a landscape's most beautiful and expressive feature. It is earth's eye; looking into which the beholder measures the depth of his own nature." ${ }^{5}$ Lakes in Egypt are very special case because they enclose many kinds of environments: desert, water and green areas in addition to the natural protectorates with in. These 
protectorates saved from ancient ages and protected by law and international agreements. The Mediterranean coastal shoreline of Egypt includes five large lakes, which constitute about 25 percent of the total wetlands in the Mediterranean region.

Figure (9) Egyptian Lakes on the Mediterranean Coast

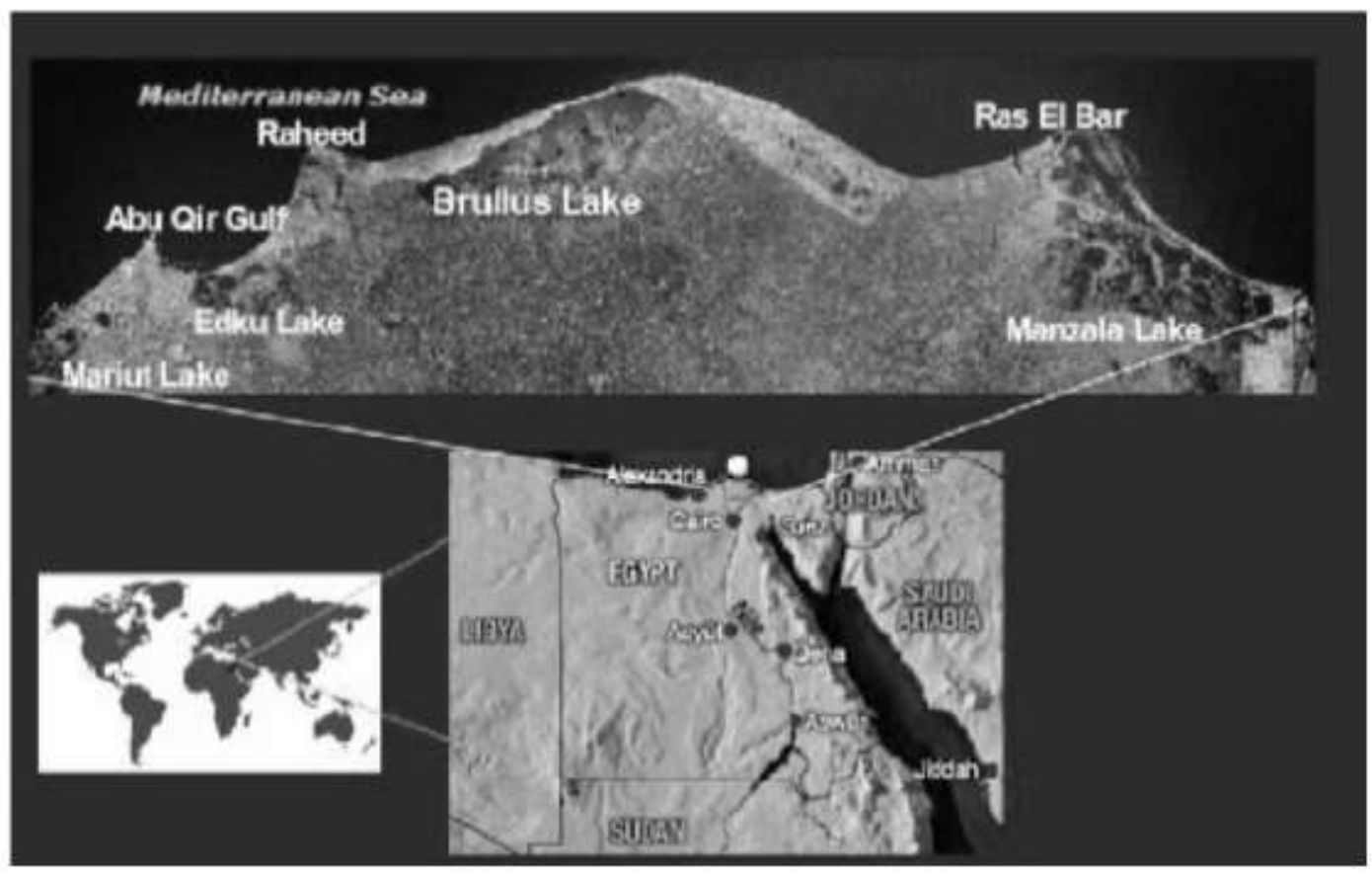

\subsubsection{Manzala Lake}

A Salt water lake In northeastern Egypt on the Nile Delta near Port Said, Damietta, Dakahlyia and Sharqyia governorates. It is separated from the Mediterranean Sea by a sandy beach ridge which has three open connections between the Lake and the Sea. These open connections allow an exchange of water between the Lake and the Sea. ${ }^{6}$

\subsubsection{Marriot Lake}

A salt lake in northern Egypt, between Alexandria and Al-Buhira (Beheira actually is named after it) Governorates.

\subsubsection{Bardawil Lake}

A Salt water Lake in North of Sinai Governorate. It is said that it is named after King Baldwin I of Jerusalem of the First Crusade and that he was buried there. ${ }^{7}$

\subsubsection{Edko Lake}

Salt water Lake in Kafr el-Sheikh Governorate.

\subsubsection{Great Bitter Lakes (al-Buhayrat al-Murrah)}


A salt water lake between the north and south part of the Suez Canal, includes Greater Bitter Lake and Lesser Bitter Lakes and el-Temmsah Lake (The crocodile lake) in Ismailia Governorate.

\subsubsection{Burullus Lake (Paralos lake)}

A Salt water Lake in North shore of River Nile Delta, Western corner in Kafr el-Sheikh Governorate. ${ }^{8}$ Burullus Lake is considered the second largest lake of the Nile delta, which is about $53 \mathrm{~km}$ long, $13 \mathrm{~km}$ wide and has water depths ranging from 0.5 to $2.5 \mathrm{~m}$ Burullus Lake is connected to the sea at its north-eastern edge through the Burullus inlet, which is about $250 \mathrm{~m}$ wide and $5 \mathrm{~m}$ deep. The northern border is separated from the Mediterranean Sea by a strip of land covered with sand bars and dunes. Seven drains and fresh water canals are connected to its eastern, southern and western shores. ${ }^{9}$

\subsubsection{Wadi El Natrun Lakes}

A salt water lake in Wadi Natron area near el-Qattara depression in Matruh Governorate, salt lakes of Siwa in New Valley Governorate, and Siwa Oasis in Western Desert. $^{10}$

\subsubsection{Moeris or Qaroun Lake}

Lake Qarun is a saline basin, located in North West of Egypt in Fayoum governorate. The lake is bounded on the east and south by the agricultural cultivated lands ${ }^{11}$. Lake Qarun is also an Important Bird Area (IBA), internationally renowned for its wintering waterfowl. ${ }^{12}$

\subsubsection{Wadi Elrayan Lakes}

Salt water Lake in Fayoum governorate

\subsubsection{Aswan (Nasser) Lake}

A vast reservoir contain river water in south of Egypt and north of Sudan behind the High Dam of Aswan on the river Nile. ${ }^{13}$

\subsubsection{Toshka Lakes}

River water Lake in south west Part of Egypt, at el-Wadi el-Gadid or New Valley Governorate.

\subsection{Potentials of Egyptian Lakes}

- The biodiversity between different environments.

- The touristic attraction elements such as monuments and ancient cities.

- Lakes are near to major cities like: Alexandria, Dumiatta, Fayoum and Aswan

- The water element is the most important element in developing the Egyptian urban communities.

- The diversity in natural resources: agricultural fields and Livestock.

\subsection{Challenges facing sustainability of Egyptian Lakes}




\subsubsection{Environmental problems}

Lakes in Egypt face many common environmental problems. Some problems are caused by water polices and management. Other problems are caused by lack of environmental awareness.

\section{Water Problems}

The four lagoons of the Mediterranean Coast (Maryut, Idku, Burullus and Manzala) contain high variation from biodiversity of natural plants, wetlands and birds. They have suffered from many problems such as beach erosion, land subsidence, sea-level rise, water pollution, land encroachments, water logging, and bad management. ${ }^{14}$ The western and southern sectors of Lake Manzala are supplied by drainage water from 7 main sources. Water from these drains enriches the lake with nutrients, including phosphate, nitrate, and silicate. In addition, some of these drains discharge considerable amounts of sewage and industrial wastes directly into the lake. The Ginka subbasin in the southeast sector of the lake is identified as a 'black spot'. SLR is expected to enhance diffusion in the coastal area and magnify the adverse effects of this pollution. ${ }^{15}$

\section{Desertification}

some of these lakes are facing the danger of desertification due to Sand dune encroachment like north side of Qaruon lake, ,Wadi Al Rayan lakes, Naser lake, Mora lakes and Wadi Natron lakes. ${ }^{16}$

\section{Abuses of the local people}

Contamination of areas surrounding the lakes of deserts and habitat due to lack of care.
Figure (10) Desertification surrounding lakes

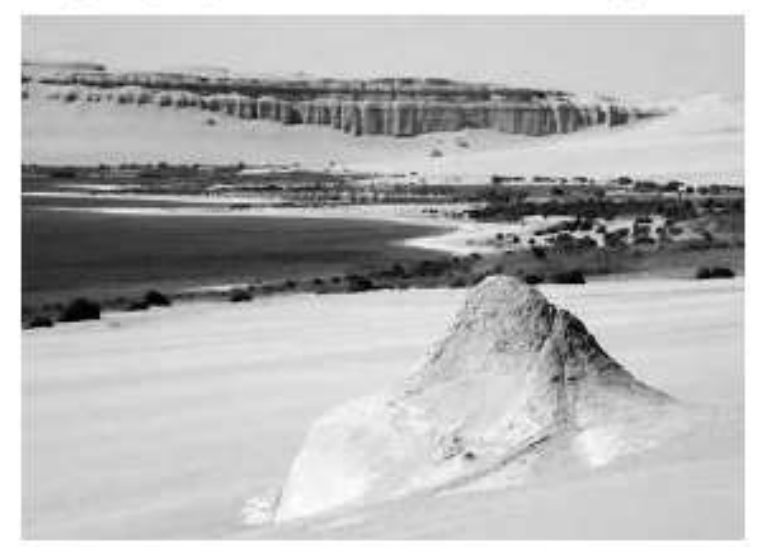

\section{Poaching}

Poaching of fish, animals and birds, which pose a threat to biodiversity.

\section{Encroachment of activities and companies}

Tourism activities that violate environmental laws by encroaching on the beaches or lakes without a study plan.

\subsubsection{Urban problems}

These include problems related to the infrastructure of cities and towns surrounding lakes which is insufficient, as well as the mal distribution of land uses and economic activities inside the unplanned urbanization. ${ }^{17}$

\subsubsection{Economic problems}

These may include unemployment spreading in areas surrounding lakes, no economic benefits promotions to encourage people to develop these lakes, and no links between the lakes and highways or train lines. ${ }^{18}$ 


\subsubsection{Social and health problems}

Most of communities surrounding lakes are suffering from lack of health and environmental awareness which due to low education ratios. ${ }^{19}$

\subsection{Conclusion and Recommendations}

Towards realizing sustainability of Egyptian Lakes it's needed to raise the social and economic level of areas surrounding these lakes without affecting environmental system this leading to development. Ecotourism is one of the tools to achieve these aims Egyptian lakes afford several activities such as fishing, agriculture in surrounding rural areas and tourism. There are some steps to upgrade Lakes ecotourism related to:

- Community: training of community and providing small touristic projects that serve ecotourism

- Urban context: upgrading road network and infrastructure of cities and towns surrounding lakes, in addition to improvement of rural communities to receive tourists.

- Environment: raising the awareness of community regarding the value of environmental control and water treatment.

\section{Notes and References}

1 Environmental Sustainability, The American Society of Landscape

2 Atmospheric correction issues for water quality assessment from Remote Sensing: the case of Lake Qarun (Egypt).

3 Implementing Sustainable Development In The Lake Kolleru, India, Roskilde University, Denmark, 2007.

4 Mufid A. Samarai, Planning Sustainable Mega Projects in UAE, World Housing Congress 2007:Affordable Quality Housing, Malaysia, 2007.

5 Same as note 3

6 Project Document Lake Manzala Engineered Wetland, United Nations Development Agency, 1997.

7 Howayda H, Nutritive And Antimicrobial Profiles Of Some Sea grasses From Bardawil Lake, Egypt, Egyptian Journal of Aquatic Research, 2007

8 Environmental monitoring program for northern lakes 2009-2010, Ministry of State for Environmental Affairs .EEAA

9 K. M. Dewidar, Detection of land use/land cover changes for the northern part of the Nile Delta (Burullus Region), Egypt, International Journal of Remote Sensing, 20 OCTOBER, 2004

10 Assessment of Environmental Impact on Wadi El-Natrun Depression Lakes Water, Egypt, World Journal of Fish and Marine Sciences, 2009 
11 Radwan G. Abd Ellah, Outlook on Past, Present and Future Status of Water Salinity in Lake Qarun, Egypt, World Journal of Fish and Marine Sciences, 2009

12 Fayoum Ecotourism Development Plan 2005-2015, Fayoum Governorate, 2006

13 Mohamed Metwaly, A hydrogeophysical study to estimate water seepage from northwestern Lake Nasser, Egypt, Journal of Geophysics and Engineering,2006

\section{Same as note 9}

15 M. El Raey, K. Dewidar, M. El Hattab, Adaptation to the impacts of sea level rise in Egypt, Institute of Graduate Studies and Research, University of Alexandria, Alexandria, 1999

16 A.Hegazi, Egyptian national action program to combat desertification, Desert Research Center (DRC), Egypt, 2005

17 Edgar Goell, Sustainable Cities in Egypt: Learning from Experience, Potential Sand Preconditions for New Cities in Desert Areas, Egyptian Cabinet Information and Decision Support Center, Center for Future Studies, 2009

18 Sami M. Abu Elenien, Economic and Social Importance of Expanding the Production and Processing of Catfish in Egypt, World Journal of Fish and Marine Sciences, 2009

19 Summary evaluation report country program ,Egypt 104500 (2007-2011), World Food Program WFP, 2011

20 E. Nikitinskiy, The situation and prospects for ecotourism development in the Republic of Kazakhstan. A Preparatory Seminar for the International Year of Ecotourism, Almaty, Republic of Kazakhstan, October 2001

21 K. Horochowski, \& R. N. Moisey, Sustainable tourism: The effect of local participation in Honduran ecotourism development. In S. F. McCool \& R. N. Moisey (Eds.), Tourism recreation and sustainability: Linking culture and the environment (pp. 163-176). UK: CABI Publishing, 2001

1 - Environmental Sustainability, The American Society of Landscape

2- Atmospheric correction issues for water quality assessment from Remote Sensing: the case of Lake Qarun (Egypt).

3 - Implementing Sustainable Development In The Lake Kolleru, India, Roskilde University, Denmark, 2007.

4 - Mufid A. Samarai, Planning Sustainable Mega Projects in UAE, World Housing Congress 2007:Affordable Quality Housing, Malaysia, 2007.

5 -Same as note 3

6 -Project Document Lake Manzala Engineered Wetland, United Nations Development Agency, 1997.

7 - Howayda H, Nutritive And Antimicrobial Profiles Of Some Sea grasses From Bardawil Lake, Egypt, Egyptian Journal of Aquatic Research, 2007 
8 -Environmental monitoring program for northern lakes 2009-2010, Ministry of State for Environmental Affairs .EEAA

9 - K. M. Dewidar, Detection of land use/land cover changes for the northern part of the Nile Delta (Burullus Region), Egypt, International Journal of Remote Sensing, 20 OCTOBER, 2004

10 - Assessment of Environmental Impact on Wadi El-Natrun Depression Lakes Water, Egypt, World Journal of Fish and Marine Sciences, 2009

11- Radwan G. Abd Ellah, Outlook on Past, Present and Future Status of Water Salinity in Lake Qarun, Egypt, World Journal of Fish and Marine Sciences, 2009

12- Fayoum Ecotourism Development Plan 2005-2015, Fayoum Governorate, 2006

13 - Mohamed Metwaly, A hydrogeophysical study to estimate water seepage from northwestern Lake Nasser, Egypt, Journal of Geophysics and Engineering,2006

14 - Same as note 9

15 - M. El Raey, K. Dewidar, M. El Hattab, Adaptation to the impacts of sea level rise in Egypt, Institute of Graduate Studies and Research, University of Alexandria, Alexandria, 1999

16 - A.Hegazi, Egyptian national action program to combat desertification, Desert Research Center (DRC), Egypt, 2005

17 - Edgar Goell, Sustainable Cities in Egypt: Learning from Experience, Potential Sand Preconditions for New Cities in Desert Areas, Egyptian Cabinet Information and Decision Support Center, Center for Future Studies, 2009

18 - Sami M. Abu Elenien, Economic and Social Importance of Expanding the Production and Processing of Catfish in Egypt, World Journal of Fish and Marine Sciences, 2009

19 - Summary evaluation report country program ,Egypt 104500 (2007-2011), World Food Program WFP, 2011

20 - E. Nikitinskiy, The situation and prospects for ecotourism development in the Republic of Kazakhstan. A Preparatory Seminar for the International Year of Ecotourism, Almaty, Republic of Kazakhstan, October 2001

21 - K. Horochowski, \& R. N. Moisey, Sustainable tourism: The effect of local participation in Honduran ecotourism development. In S. F. McCool \& R. N. Moisey (Eds.), Tourism recreation and sustainability: Linking culture and the environment (pp. 163-176). UK: CABI Publishing, 2001 